Article

\title{
Biochemical, Microbiological, and Sensory Properties of Dried Silver Carp (Hypophthalmichthys molitrix) Influenced by Various Drying Methods
}

\author{
Md. Golam Rasul ${ }^{1}$ (D), Bhaskar Chandra Majumdar ${ }^{1}$ (D), Faria Afrin ${ }^{1}$, \\ Mohammad Abu Jafor Bapary ${ }^{2}$ (D) and A.K.M. Azad Shah 1,* (D) \\ 1 Department of Fisheries Technology, Faculty of Fisheries, Bangabandhu Sheikh Mujibur Rahman \\ Agricultural University, Gazipur 1706, Bangladesh; rasul@bsmrau.edu.bd (M.G.R.); \\ bhaskar.bsmrau@gmail.com (B.C.M.); faria3019@gmail.com (F.A.) \\ 2 Department of Fisheries Technology and Quality Control, Sylhet Agricultural University, \\ Sylhet 3100, Bangladesh; jafor_bau@yahoo.com \\ * Correspondence: azad@bsmrau.edu.bd; Tel.: +880-29205331
}

Received: 3 May 2018; Accepted: 20 June 2018; Published: 25 June 2018

\begin{abstract}
An experiment was performed to evaluate the effects of different drying methods with different pre-treatments on the physico-chemical, microbiological, and sensory properties of the silver carp, Hypophthalmichthys molitrix. In order to achieve this objective, the collected fresh fish were dried using traditional (without any pre-treatment), improved (fish soaked in a $5 \%$ salt solution for $10 \mathrm{~min}$ and then treated with chili powder $(0.3 \%)$ and turmeric powder $(0.3 \%))$, and solar tunnel (fish soaked in a $5 \%$ salt solution for $10 \mathrm{~min}$ ) drying methods. The results showed that the dried fish produced by the solar tunnel drying method were rehydrated more rapidly than the products produced by the traditional and improved drying methods. The moisture content of the dried H. molitrix was varied from 18.24 to $25.43 \%$ on a fresh matter basis. There was no significant $(p>0.05)$ difference found regarding the protein, lipid, and ash content among the different drying methods on a dry matter basis. The total volatile base nitrogen (TVB-N) contents ranged between 37.58 and $45.03 \mathrm{mg} / 100 \mathrm{~g}$, and significantly $(p<0.05)$ the lowest TVB-N was observed in dried fish produced by the solar tunnel drying method. Moreover, the highest peroxide and acid values were found in the traditionally produced dried fish as compared with the fish dried by the improved and solar tunnel drying methods. The aerobic plate count of dried fish ranged from 4.52 to $7.51 \log$ CFU/g. The sensory evaluation results revealed that the solar-dried products showed superior quality than the products produced by the traditional and improved drying methods. The results revealed that the dried fish produced by the solar tunnel drying method provided the best product in terms of physico-chemical, microbiological, and sensory aspects.
\end{abstract}

Keywords: drying methods; chemical composition; silver carp; sensory properties

\section{Introduction}

Low-cost fish preservation, such as sun drying, is a popular technique not only used in Bangladesh but also all over the world. Dried fish is one of the most important sources of animal protein and other essential nutrients for the maintenance of a healthy body [1]. Moreover, Bangladeshi people from northeastern, central, and coastal areas highly prefer this dried fish due to its characteristic taste and flavor. On a per unit weight basis, dried fish retains comparatively higher amounts of essential nutrients compared with fresh fish. In Bangladesh, the sun drying of fish has been practiced since time immemorial. The activity of the muscle enzymes and the microorganisms are halted 
by reducing the moisture content of fish [2]. However, the physical and sensory qualities of many traditional sun-dried fishery products available in the local market are not satisfactory for human consumption. Insect infestation by blow fly and beetle larvae in fish is one of the major problems related to traditional sun drying. Netting and neem (Azadirachta indica) leaves are generally used to minimize this problem. Moreover, chili powder and turmeric powder are also used to protect fish from insects during drying [3]. Another major problem of dried fish products is microbial and fungal growth, which can be reduced by maintaining proper drying and packaging of the product.

Nowadays, dried fish processors usually use insecticides to keep insects away during the drying and storage of the products, which creates serious human health complications. As a result, the biochemical properties of the dried fish are changed greatly due to such drying practices. Thus, traditionally produced dried fish are not safe for human consumption due to the random use of different kinds of pesticides and the extreme level of insect infestation [4]. To eliminate quality loss of dried fish products, different kinds of drying methods with different pre-treatments of fish have been established [5,6]. Solar tunnel drying is one such method, and it is easy to accomplish with locally available materials and does not require any power from an electrical grid [7].

The silver carp (Hypophthalmichthys molitrix) is one of the most widely cultivated species of fish all over the world due to its high yielding potentiality, ease of cultivation, efficient utilization of supplementary feed, and the fact that it contains essential nutrients for human health. In 2016-2017, the total fish production of Bangladesh was 4,134,434 metric tons; among this, silver carp production was 226,175 metric tons [8]. However, the taste of cooked silver carp is comparatively less palatable than the other major Indian carps. For this reason, consumers do not prefer to eat it as a regular dish; although, the price is found to be reasonable. Due to its relatively lower price, dried fish products can be made to add value to obtain more commercial benefits from this species. Thus, there is an opportunity to develop a dried product of this species that might improve the quality, taste, and consumer acceptability of this fish. Moreover, it is important to develop quality dried fishery products for export earning. Therefore, this study was aimed to evaluate the effects of different drying methods with different pre-treatments on the quality and sensory properties of dried silver carp (H. molitrix).

\section{Results}

\subsection{Water Reconstitution of Sun-Dried Fish}

The water reconstitution of sun-dried fish produced by the different drying methods is shown in Figure 1 . The results showed that the traditionally produced dried silver carp held $41.43 \%$ moisture after $60 \mathrm{~min}$ at room temperature, whereas better moisture-holding capacity was observed in the dried fish produced by the improved (49.21\%) and the solar tunnel (54.94\%) drying methods. A similar trend was also observed when dried fish were soaked at $40^{\circ} \mathrm{C}$ and $60^{\circ} \mathrm{C}$ for $60 \mathrm{~min}$. 

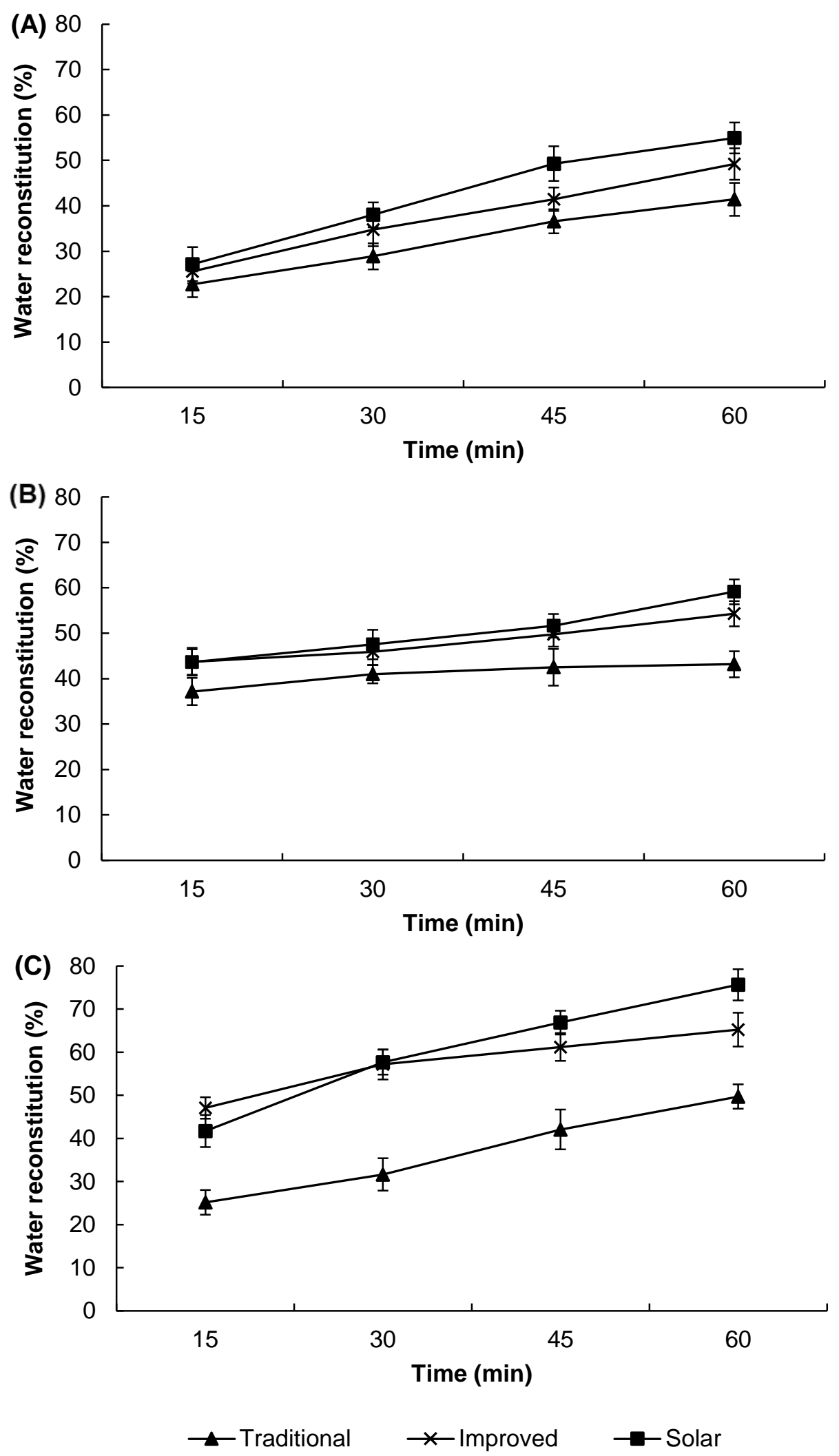

Figure 1. Water reconstitution of Hypophthalmichthys molitrix at (A) room temperature, (B) $40{ }^{\circ} \mathrm{C}$ and (C) $60{ }^{\circ} \mathrm{C}$ for the different drying methods. 


\subsection{Changes in $p H$ Value}

The $\mathrm{pH}$ values of the dried fish produced by the different drying methods are shown in Figure 2. The $\mathrm{pH}$ values of dried silver carp ranged from 6.33 to 6.65 . Significantly $(p<0.05)$ the highest $\mathrm{pH}$ value was observed in the traditionally produced dried fish, while the lowest value (6.33) was found in dried fish produced by the solar tunnel drying method.

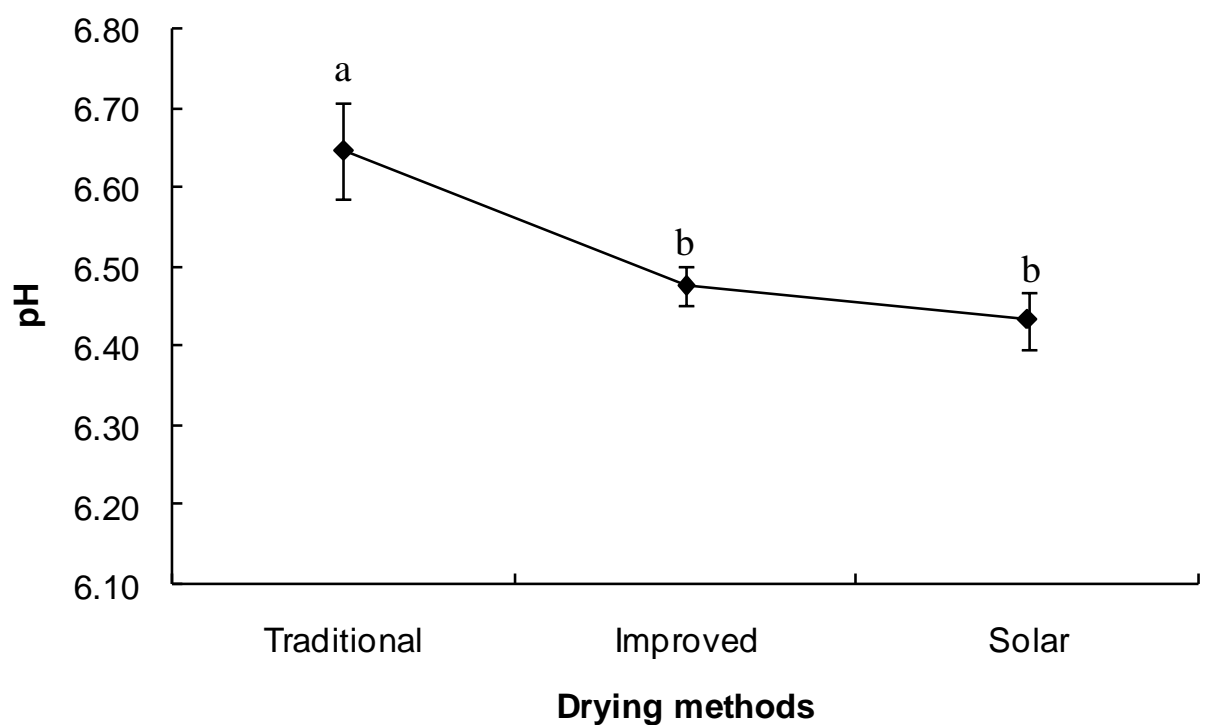

Figure 2. Changes in $\mathrm{pH}$ value of $H$. molitrix in various drying methods.

\subsection{Proximate Composition of Dried Silver Carp}

The moisture content of the dried H. molitrix ranged from $18.24 \%$ to $25.43 \%$ on a fresh matter basis (Table 1). Comparatively higher moisture content was found in the traditionally produced dried fish when compared with the dried fish produced by the improved and solar tunnel drying methods. However, the highest protein content was observed in the dried fish $(83.68 \%)$ produced by the solar tunnel drying method, and the lowest protein content was found in the dried fish (82.49\%) produced traditionally. The lipid content of dried fish ranged between $8.32 \%$ and $8.77 \%$ on a dry matter basis. The ash content of dried fish ranged from $7.51 \%$ to $9.11 \%$ on a dry matter basis.

Table 1. Effect of drying methods on the proximate composition (\%) of H. molitrix. Each value is expressed as a mean \pm standard deviation (SD) $(n=3)$. Means with different superscripts $(\mathrm{a}, \mathrm{b}$ : fresh matter; $\mathrm{d}$ : dry matter) within a column are significantly different $(p<0.05)$. ${ }^{*}$ Figures in parenthesis indicate values on a dry matter basis.

\begin{tabular}{ccccc}
\hline DRYING METHODS & Moisture & Protein & Lipid & Ash \\
\hline \multirow{2}{*}{ Traditional } & $25.43 \pm 1.07^{\mathrm{a}}$ & $61.51 \pm 1.11^{\mathrm{b}}$ & $6.21 \pm 0.93^{\mathrm{a}}$ & $6.79 \pm 1.11^{\mathrm{a}}$ \\
& & $\left(82.49 \pm 1.48^{\mathrm{d}}\right)^{*}$ & $\left(8.32 \pm 1.25^{\mathrm{d}}\right)$ & $\left(9.11 \pm 1.48^{\mathrm{d}}\right)$ \\
\hline \multirow{2}{*}{ Improved } & $19.83 \pm 0.47^{\mathrm{b}}$ & $65.44 \pm 1.02^{\mathrm{a}}$ & $6.81 \pm 0.72^{\mathrm{a}}$ & $6.49 \pm 1.29^{\mathrm{a}}$ \\
& & $\left(82.88 \pm 1.27^{\mathrm{d}}\right)$ & $\left(8.75 \pm 0.93^{\mathrm{d}}\right)$ & $\left(8.34 \pm 1.66^{\mathrm{d}}\right)$ \\
\hline \multirow{2}{*}{ Solar } & $18.24 \pm 0.16^{\mathrm{b}}$ & $68.41 \pm 0.61^{\mathrm{a}}$ & $7.04 \pm 1.58^{\mathrm{a}}$ & $6.03 \pm 1.01^{\mathrm{b}}$ \\
& & $\left(83.68 \pm 0.75^{\mathrm{d}}\right)$ & $\left(8.77 \pm 1.97^{\mathrm{d}}\right)$ & $\left(7.51 \pm 1.26^{\mathrm{d}}\right)$ \\
\hline
\end{tabular}

\subsection{Changes of Total Volatile Base Nitrogen Value}

The total volatile base nitrogen (TVB-N) values of the dried silver carp produced by the different drying methods are shown in Figure 3. The TVB-N values of the solar, improved, and traditionally 
produced dried silver carp were $37.58 \mathrm{mg} / 100 \mathrm{~g}, 40.05 \mathrm{mg} / 100 \mathrm{~g}$, and $45.03 \mathrm{mg} / 100 \mathrm{~g}$ of muscle, respectively. Significantly $(p<0.05)$, the highest TVB-N value was observed in the dried fish produced by the traditional drying method, while the lowest value was found in the dried fish produced by the solar tunnel drying method.

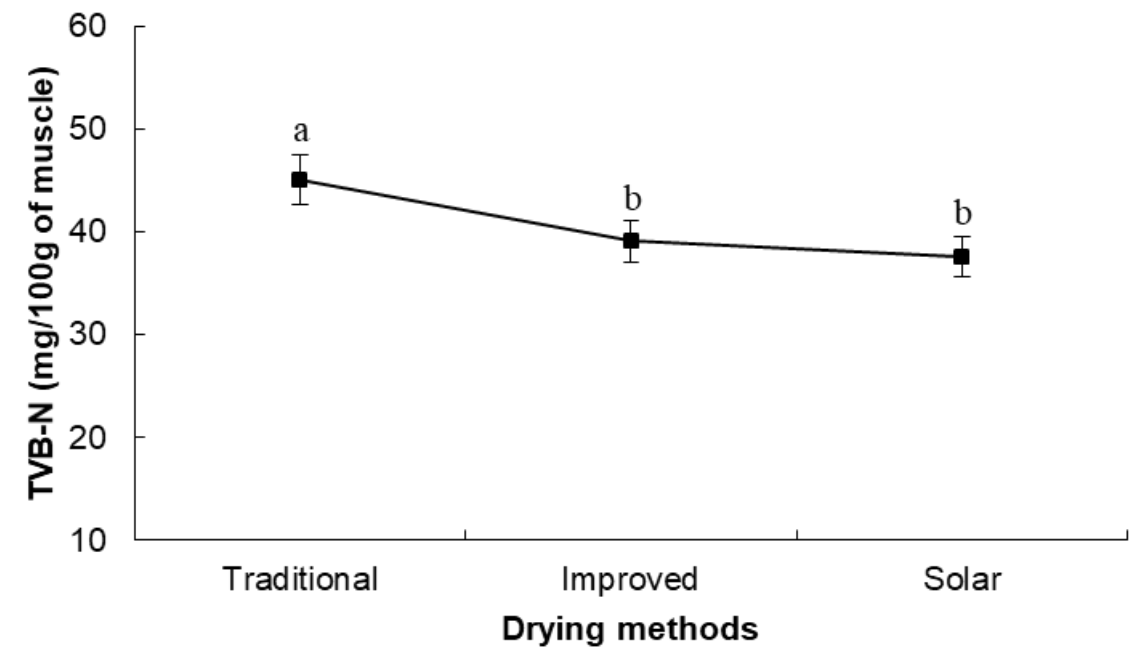

Figure 3. Total volatile base nitrogen (TVB-N) of H. molitrix in different drying methods.

\subsection{Lipid Oxidation}

The peroxide value and acid value were determined to measure the degree of lipid oxidation in the dried fish. The peroxide value of the dried fish ranged from 9.16 to $15.50 \mathrm{meq} / \mathrm{kg}$ lipid (Table 2). The acid values of dried H. molitrix ranged from 7.85 to $18.87 \mathrm{mg} \mathrm{KOH} / \mathrm{g}$ of lipid.

Table 2. Effect of the drying methods on the peroxide value and acid value of $H$. molitrix. Each value is expressed as a mean $\pm \mathrm{SD}(n=3)$. Means with different superscripts within a column are significantly different $(p<0.05)$.

\begin{tabular}{ccc}
\hline Drying Methods & Peroxide Value (meq/kg of Lipid) & Acid Value (mg KOH/g of Lipid) \\
\hline Traditional & $15.50 \pm 0.93^{\mathrm{a}}$ & $18.87 \pm 0.85^{\mathrm{a}}$ \\
Improved & $11.68 \pm 1.23^{\mathrm{b}}$ & $12.20 \pm 1.05^{\mathrm{b}}$ \\
Solar & $9.16 \pm 0.96^{\mathrm{c}}$ & $7.85 \pm 0.45^{\mathrm{c}}$ \\
\hline
\end{tabular}

\subsection{Microbiological Load of Dried Fish Products}

The aerobic plate count (APC) of dried silver carp varied between 4.52 and $7.51 \mathrm{log}$ CFU/g (Table 3). Comparatively higher APC was found in the traditionally produced dried fish as compared with the dried fish produced by the improved and solar tunnel drying methods.

Table 3. Effect of the drying methods on microbial load (aerobic plate count (APC)) of H. molitrix.

\begin{tabular}{cc}
\hline Drying Methods & Aerobic Plate Count (log CFU/g) \\
\hline Traditional & 7.51 \\
Improved & 5.15 \\
Solar & 4.52 \\
\hline
\end{tabular}

\subsection{Sensory Characteristics of Dried Fish Products}

Significantly the highest values of color, odor, texture, and insect infestation were found in the traditionally produced dried fish when compared with the dried fish produced by the improved and 
solar tunnel drying methods (Table 4). The dried fish produced by the solar tunnel drying method was excellent in quality according to the sensory properties, such as color, odor, texture, and insect infestation. On the other hand, the dried fish produced by the improved drying method was also found to be of good quality, whereas the traditionally produced dried H. molitrix had decreased in quality.

Table 4. Effect of the drying methods on the sensory properties of H. molitrix. Each value is expressed as a mean $(1-10$ scoring $) \pm S D(n=3)$. Means with different superscripts within a column are significantly different $(p<0.05)$.

\begin{tabular}{cccccc}
\hline Drying Methods & Color & Odor & Texture & Insect Infestation & Overall Acceptability \\
\hline Traditional & $2.81 \pm 0.33^{\mathrm{a}}$ & $2.38 \pm 0.40^{\mathrm{a}}$ & $3.27 \pm 0.20^{\mathrm{a}}$ & $4.96 \pm 0.16^{\mathrm{a}}$ & $13.42 \pm 0.46^{\mathrm{a}}$ \\
Improved & $1.93 \pm 0.25^{\mathrm{b}}$ & $1.56 \pm 0.53^{\mathrm{b}}$ & $2.18 \pm 0.16^{\mathrm{b}}$ & $1.20 \pm 0.18^{\mathrm{b}}$ & $6.87 \pm 0.27^{\mathrm{b}}$ \\
Solar & $1.69 \pm 0.20^{\mathrm{c}}$ & $1.22 \pm 0.20^{\mathrm{b}}$ & $1.93 \pm 0.15^{\mathrm{b}}$ & $1.03 \pm 0.06^{\mathrm{b}}$ & $5.87 \pm 0.31^{\mathrm{b}}$ \\
\hline
\end{tabular}

\section{Discussion}

Dried fish is a very popular processed food item, not only among consumers of Bangladesh but also in many other countries of the world. Dried fish are usually prepared by various drying methods with different pre-treatments, which play a vital role in the biochemical, microbiological, and sensory properties of the dried fish. Generally, the water-holding capacity of dried fish is increased with the increase of water temperature and soaking time. Overall, the dried fish produced by the solar tunnel drying method was rehydrated more rapidly than the dried fish produced by the improved or traditional drying methods. It has been reported that increased water temperature may open the internal structure of the fish muscle, which accelerates the rate of water absorption $[9,10]$. Reza et al. [11] also reported that rehydration ability is positively influenced by the physical properties of dried fish. Moreover, the water absorption capacity of dried fish depends on the variation of species in addition to time and temperature $[10,12]$.

The determination of $\mathrm{pH}$ in fish muscle is an important index for quality assessment. In this study, $\mathrm{pH}$ values varied with the drying methods. However, no significant variation was observed in $\mathrm{pH}$ values between the dried fish produced by the improved and solar tunnel drying methods. The lowest $\mathrm{pH}$ values of dried fish produced by the solar tunnel drying method may inhibit microbial growth and extended the shelf life by reducing the activity of the endogenous enzyme. Moreover, the quality of dried fish improved when the $\mathrm{pH}$ value was decreased [13].

In this study, the moisture content was $25.43 \%, 19.83 \%$, and $18.24 \%$ in the dried fish produced by the traditional, improved, and solar tunnel drying methods, respectively. The variation of moisture content in the dried fish might be the effect of the different drying methods. Comparatively lower amounts of moisture content were observed in the improved and solar-dried products, where fish was soaked in a salt solution that helped to reduce the water activity of the fish more rapidly. Generally, higher moisture content may enhance mold/fungal growth in the traditionally produced dried fish. Hasan et al. [14] reported that the moisture contents of traditional and solar-dried products of some small indigenous species ranged from $26.02 \%$ to $27.33 \%$ and $13.71 \%$ to $19.30 \%$, respectively. After drying, the protein content was $61.51 \%, 65.44 \%$, and $68.41 \%$ in the dried fish produced by the traditional, improved, and solar tunnel drying methods, respectively. Protein content was increased in the dried fish due to the dehydration of water molecules present between the proteins, causing the aggregation of protein [15]. But, there was no significant $(p>0.05)$ difference observed in the protein, lipid, or ash content in the dried fish produced by the various drying methods on a dry matter basis. The lowest lipid content was observed in the dried fish produced by the traditional drying method, which might be due to comparatively higher oxidation of lipids than the other drying methods. The highest amount of ash was found in the traditionally produced dried fish, which might be associated with contamination by sands and dirt during drying. It has been reported that the biochemical composition, such as moisture, ash and free fatty acid content, was lower in the dried fish 
produced by the solar tunnel drying method, whereas the values of protein and lipid were higher in the dried fish produced by the improved and traditional drying methods [16].

A number of volatile base nitrogenous compound, such as ammonia, dimethylamine, and trimethylamine, are released in fish during decomposition by bacteria. The TVB-N values of the dried silver carp ranged between $37.58 \mathrm{mg} / 100 \mathrm{~g}$ and $45.03 \mathrm{mg} / 100 \mathrm{~g}$ of muscle, which is much lower than the recommended value (100-200 mg/100 g of muscle) for different dried and salted fish products [17]. It has been reported that the TVB-N value of dried tilapia fillets ranged between 44.27 and $64.39 \mathrm{mg} / 100 \mathrm{~g}$ of muscle [18].

The oxidation of lipids in fish muscle usually develops off-flavor and off-odor that ultimately affect the storage time [19]. The highest peroxide value and acid value were determined in the dried fish produced by the traditional method, and the lowest values were observed in the dried fish produced by the solar tunnel drying method. The peroxide values (PV) observed in this study were lower than the recommended value ( $\mathrm{PV} \leq 20 \mathrm{meq} / \mathrm{kg}$ fish lipid) [17]. It has been reported that the peroxide value of herring (Clupea pallasii) lipids (5.52-11.86 meq/ $\mathrm{kg}$ ) increased significantly during the drying period [20]. Generally, lower acid values indicate better quality of a product. In this study, the acid values ranged from 7.85 to $18.87 \mathrm{mg} \mathrm{KOH} / \mathrm{g}$ of lipid, which is more or less similar with the results reported by Majumdar et al. [21]. The formation of free fatty acid is one of the important factors that increases the acid value in the dried fish. Moreover, these free fatty acids were further oxidized and produced secondary oxidation products, which generated characteristic taste and off-odor of fish and fishery products [22].

Quantitative microbiological analysis helps to evaluate the quality of dried fish. The APC were $7.51,5.15$, and $4.52 \log \mathrm{CFU} / \mathrm{g}$ in the dried fish produced by the traditional, improved, and solar tunnel drying methods, respectively. It has been reported that the acceptable limit of total plate count for fresh fish is $7 \log$ CFU/g [23]. The APC of some marine dried fish range between 3.27 and $4.49 \log$ CFU/g [24]. Mansur et al. [25] reported that the total bacterial count of some sun-dried fishes range between 1.84 and $5.3 \log \mathrm{CFU} / \mathrm{g}$.

Sensory analysis such as color, odor, texture, and insect infestation of dried fish were evaluated to estimate quality using panel members' senses. The overall acceptability was $13.42,6.87$, and 5.87 in the dried fish produced by the traditional, improved, and solar tunnel drying methods, respectively. It has been suggested that a lower sensory score of a dried fish indicates better quality of the products and vice versa [26]. The traditionally produced sun-dried fish showed objectionable color, odor, and texture, whereas the dried fish produced by the solar tunnel drying method showed comparatively better quality in every aspect [27]. Our results suggested that the dried fish produced by the solar tunnel drying method showed comparatively better quality than the dried fish produced by the traditional and improved drying methods.

\section{Material and Methods}

\subsection{Collection of Samples}

Fresh silver carp (H. molitrix) (weight $405.47 \pm 41.13 \mathrm{~g}$ and length $28.4 \pm 4.03 \mathrm{~cm}$ ) were purchased from a local market situated at Gazipur, Bangladesh $\left(23^{\circ} 99^{\prime} 17^{\prime \prime} \mathrm{N}, 90^{\circ} 41^{\prime} 96^{\prime \prime}\right.$ E). The fish were transported for drying to the laboratory in the Department of Fisheries Technology, Faculty of Fisheries, Bangabandhu Sheikh Mujibur Rahman Agricultural University, in an insulated ice box. The fish were dried for about six days, until moisture content was reduced to approximately $20 \%$ in the final product, during the month of February.

\subsection{Traditional Sun Drying Method}

In the traditional sun drying method, the collected fish were dressed and spread on bamboo mats without any pre-treatment, such as icing, salting, and cleaning for sun drying. The dried fish were stored in a freezer at $-20^{\circ} \mathrm{C}$ for further use. 


\subsection{Improved Sun Drying Method}

According to the method of Immaculate et al. [16], in the improved sun drying method, the fish were properly gutted, washed, and soaked in a salt solution (5\% per body weight) for $10 \mathrm{~min}$ and then treated with chili powder $(0.3 \%)$ and turmeric powder $(0.3 \%)$. The treated fish were hung on a rack. The sun-dried fish were stored in a freezer at $-20{ }^{\circ} \mathrm{C}$ for further use.

\subsection{Solar Tunnel Drying Method}

In the solar tunnel drying method, the fish were dried following the method described by Nowsad [3]. Briefly, the fish were properly gutted, washed, and soaked in a brine solution (5\% salt) for $10 \mathrm{~min}$, and then, the treated fish were hung in a dryer. The dried fishes were stored in a freezer at $-20{ }^{\circ} \mathrm{C}$ for subsequent analysis.

\subsection{Determination of Water Reconstitution}

Water reconstitution behavior was investigated following the method described by Hasan et al. [28] with slight modification. Briefly, about 8-10 $\mathrm{g}$ of the sample was weighed and submerged into water at room temperature $\left(26-28{ }^{\circ} \mathrm{C}\right), 40{ }^{\circ} \mathrm{C}$, and $60{ }^{\circ} \mathrm{C}$ for $60 \mathrm{~min}$. The soaked dried fish was taken out from the water at $15 \mathrm{~min}$ intervals and reweighed. The water reconstitution percentage was calculated using the following formula:

$$
\text { Water reconstitution }(\%)=\frac{W_{r}-W_{i}}{W_{i}} \times 100
$$

where $W_{i}$ is the initial weight of the dried fish and $W_{r}$ is the final weight of the rehydrated dried fish.

\subsection{Measurement of $\mathrm{pH}$ Value}

The dried fish $(10 \mathrm{~g})$ was homogenized with $100 \mathrm{~mL}$ of distilled water, and the $\mathrm{pH}$ was directly determined using a pH meter (MeterLab PHM 310, Beijing, China).

\subsection{Analysis of Proximate Composition}

The proximate composition such as moisture, crude protein, crude lipid and ash content were analyzed according to standard procedure given in Association of Official Analytical Chemists (AOAC) methods [29].

\subsection{Determination of Total Volatile Basic Nitrogen}

The TVB-N was determined following the method of Antonacopoulos and Vyncke [30]. The value was expressed as $\mathrm{mg} / 100 \mathrm{~g}$ of muscle.

\subsection{Extraction of Lipids}

The total lipids were extracted from the dried fish with a solvent combination of chloroform:methanol:distilled water according to the method of Bligh and Dyer [31], with slight modification making those final ratios 10:5:3, $v / v / v$. The extracted lipids were stored in chloroform at $-20^{\circ} \mathrm{C}$ until further analysis.

\subsection{Measurement of Peroxide Value}

The peroxide value was measured according to AOAC methods [29]. About $0.5 \mathrm{~g}$ of total lipids were added to a glacial acetic acid:chloroform solution $(3: 2, v / v)$ in a conical flask. Saturated potassium iodide $(0.5 \mathrm{~mL})$ was added to the mixture and kept in the dark for $10 \mathrm{~min}$. Then, distilled water $(30 \mathrm{~mL})$ and freshly prepared $1 \%$ starch solution $(0.5 \mathrm{~mL})$ were added to the mixture. The solution was shaken and titrated with $0.01 \mathrm{~mol} / \mathrm{L}$ sodium thiosulfate. The result was expressed as meq $/ \mathrm{kg}$ of lipid. 


\subsection{Determination of Acid Value}

To measure acid value, $0.5 \mathrm{~g}$ of the total lipids were mixed with an ethanol:diethyl ether solution $(1: 1, v / v)$, and phenolphthalein was added to it. The mixture was then titrated with $0.01 \mathrm{~mol} / \mathrm{L}$ potassium hydroxide. The result was expressed as $\mathrm{mg} \mathrm{KOH} / \mathrm{g}$ lipid [29].

\subsection{Microbiological Analysis}

The microbial load of the dried fish was estimated using the aerobic plate count method. Physiological saline solution $(0.85 \% \mathrm{NaCl})$ and plate count agar (Hi media, Mumbai, India) were prepared according to the methods given in Cowan and Steel's manual [32].

\subsection{Sensory Characteristics}

Color, odor, texture, and insect infestation of the dried fish produced by the different drying methods with different pre-treatments were examined by sensory analysis according to the method described by Roy [26], which is shown in Table 5.

Table 5. Characteristic score for determining the sensory quality of dried fish.

\begin{tabular}{llll}
\hline $\begin{array}{l}\text { Sensory } \\
\text { Characteristics }\end{array}$ & Description & Score & Comment on Quality \\
\hline \multirow{4}{*}{ Color } & Characteristic color for every treatment & $1-2.99$ & Excellent \\
& Slightly brownish/whitish/yellowish & $3-5.99$ & Average \\
& Brownish/Faded & $6-7.99$ & Moderately unacceptable \\
& Darkish color & $8-10$ & Highly unacceptable \\
\hline \multirow{5}{*}{ Odor } & Characteristic fishy odor & $1-2.99$ & Excellent \\
& Slight decrease of dry fish odor & $3-5.99$ & Good \\
& Slightly rancid & $6-7.99$ & Average \\
& Prominence of herbal odor/absence of dry fish/rancid & $8-10$ & Poor in quality and unacceptable \\
\hline \multirow{5}{*}{ Texture } & Firm and flexible & $1-2.99$ & Excellent \\
& Some loss of firmness and elasticity & $3-5.99$ & Average \\
& Soft in texture & $6-7.99$ & Poor in quality and unacceptable \\
& Fragile/Fragmented & $8-10$ & Unacceptable \\
\hline & No infestation & $1-2.99$ & Excellent \\
& Few insect infestation & $3-5.99$ & Average \\
& Moderate insect infestation & $6-7.99$ & Poor in quality and unacceptable \\
& Heavy insect infestation & $8-10$ & Unacceptable \\
\hline
\end{tabular}

\subsection{Statistical Analysis}

All the analyses were carried out by one-way analysis of variance (ANOVA). All the data are expressed as mean \pm standard deviation (SD). Duncan's multiple range test was performed to compare the means at a 5\% level of significance. All analyses were performed using statistical software, Statgraphics (StatPoint Inc., Herndon, VA, USA) version 7.0.

\section{Conclusions}

The results of this study revealed that different drying methods with different pre-treatments have a significant role on the physico-chemical, microbiological, and sensory properties of the dried silver carp. Water reconstitution, $\mathrm{pH}$, and sensory characteristics were highly acceptable for the solar dried fish products, where fish were pre-treated with salt solution only. The traditionally produced dried fish were of comparatively poor quality in terms of proximate composition, TVB-N, peroxide value, acid value, and aerobic plate count when compared with the improved and solar dried fish products. Our results indicate that the dried fish produced by the solar tunnel drying method showed comparatively better quality than the dried fish produced by the improved and traditional drying methods. 
Author Contributions: M.G.R. and A.K.M.A.S. conceived of and designed the study. B.C.M. and F.A. performed the experiments, while M.A.J.B. analyzed the data. M.G.R. and A.K.M.A.S contributed reagents/materials/analysis tools. M.G.R led the writing of the manuscript with contributions from all authors.

Funding: The work was financially supported by the Research Management Committee (RMC) of Bangabandhu Sheikh Mujibur Rahman Agricultural University (BSMRAU), Gazipur and the University Grant Commission (UGC), Bangladesh.

Acknowledgments: The authors wish to thank Mueena Jahan, Department of Microbiology and Public Health of BSMRAU, Gazipur for helping with the microbiological analysis.

Conflicts of Interest: The authors declare no conflict of interest.

\section{References}

1. Arannilewa, S.T.; Salawu, S.O.; Sorungbe, A.A.; Ola-Salawu, B.B. Effect of frozen period on the chemical, microbiological and sensory quality of frozen tilapia fish (Sarotherodun galiaenus). Afr. J. Biotechnol. 2005, 4, 852-855. [CrossRef] [PubMed]

2. Humayun, N.M. Studies on the Improvement of Traditional Preservation Method of Fish Drying to Augment the Quality and the Shelf Life of the Product. Master's Thesis, Department of Fisheries Technology, Bangladesh Agricultural University, Mymensingh, Bangladesh, 1995.

3. Nowsad, A.K.M. Participatory Training of Trainers. A New Approach Applied in Fish Processing, 1st ed.; Bangladesh Fisheries Research Forum: Dhaka, Bangladesh, 2005; p. 150.

4. Bhuiyan, M.N.H.; Bhuiyan, H.R.; Rahim, M.; Ahmed, K.; Haque, K.M.F.; Hassan, M.T.; Bhuiyan, M.N.I. Screening of organochlorine insecticides (DDT and heptachlor) in dry fish available in Bangladesh. Bangladesh J. Pharmacol. 2008, 3, 114-120. [CrossRef]

5. Kumar, G.P.; Xavier, K.A.M.; Nayak, B.B.; Kumar, H.S.; Venkateshwarlu, G.; Balange, A.K. Effect of different drying methods on the quality characteristics of Pangasius hypophthalmus. Int. J. Curr. Microbiol. Appl. Sci. 2017, 6, 184-195. [CrossRef]

6. Roy, V.C.; Kamal, M.; Faridullah, M.; Haque, S.A.; Reza, M.S. Influence of salt and herbal substance on the drying and reconstitution performance of Bombay duck, Harpodon nehereus. J. Fish. 2014, 2, 59-63. [CrossRef]

7. Nowsad, A.K.M. New method of drying fish in solar fish dryer. In Empowerment of Coastal Fishing Community Project; Food and Agricultural Organization of the United Nations: Rome, Italy, 2003; p. 5.

8. Department of Fisheries (DoF). Yearbook of Fisheries Statistics of Bangladesh 2016-17; Fisheries Resources Survey System (FRSS), DoF: Dhaka, Bangladesh, 2017; Volume 34, pp. 1-129.

9. Brennan, J.G.; Butters, J.R.; Cowell, N.D.; Lilly, A.E.V. Food Engineering Operations, 3rd ed.; Elsevier Applied Science: London, UK, 1990; pp. 123-130.

10. Akintunde, T.Y. Effect of soaking water temperature and time on some rehydration characteristics and nutrient loss in dried bell pepper. Agric. Eng. Int. CIGR J. 2008, 10, 8-13.

11. Reza, M.S.; Bapary, M.A.J.; Azimuddin, K.M.; Nurullah, M.; Kamal, M. Studies on the traditional drying activities of commercially important marine fishes of Bangladesh. Pak. J. Biol. Sci. 2005, 8, 1303-1310.

12. Nurullah, M. Quality Assessment and Improvement of Traditionally Dried Small Indigenous Fish of Bangladesh. Ph.D. Thesis, Department of Fisheries Technology, Bangladesh Agricultural University, Mymensingh, Bangladesh, 2005.

13. Farid, F.B.; Latifa, G.A.; Nahid, M.N.; Begum, M. Comparison of the changes in physico-chemical characteristics of dry salted Snake-head shoal (Channa striatus Bloch, 1801) and Taki (Channa punctatus Bloch, 1793) at room temperature $\left(27^{\circ} \mathrm{C}\right.$ to $\left.31^{\circ} \mathrm{C}\right)$. Res. J. Anim. Vet. Fish. Sci. 2014, 2, 18-23.

14. Hasan, M.M.; Shikha, F.H.; Hossain, M.I.; Kamal, M.; Islam, M.N.; Wahab, M.A. Quality assessments of traditional, rotary and solar tunnel dried small indigenous fish products. Bangladesh J. Fish. Res. 2006, 10, 73-84.

15. Ninawe, A.S.; Rathnakumar, K. Impact of curing. In Fish processing Technology and Product Development, 1st ed.; Narendra Publishing House: Delhi, India, 2008; p. 142.

16. Immaculate, J.; Sinduja, P.; Jamila, P. Biochemical and microbial qualities of Sardinella fimbriata sun dried in different methods. Int. Food Res. J. 2012, 19, 1699-1703.

17. Connell, J.J. Control of Fish Quality, 4th ed.; Fishing News Books: Oxford, UK, 1995; p. 256. 
18. Gamal, F.M.; Eman, M.H.; Latef, M.A. Physicochemical properties and mycotoxins contents of tilapia fish fillets after solar drying and storage. Glob. Vet. 2011, 7, 138-148.

19. Ramanathan, L.; Das, N.P. Studies on the control of lipid oxidation in ground fish by some polyphenolic natural products. J. Agric. Food Chem. 1992, 40, 17-21. [CrossRef]

20. Shah, A.K.M.A.; Tokunaga, C.; Kurihara, H.; Takahashi, K. Changes in lipids and their contribution to the taste of migaki-nishin (dried herring fillet) during drying. Food Chem. 2009, 115, 1011-1018. [CrossRef]

21. Majumdar, B.C.; Afrin, F.; Rasul, M.G.; Khan, M.; Shah, A.K.M.A. Comparative study of physico-chemical, microbiological and sensory aspects of some sun dried fishes in Bangladesh. Braz. J. Biol. Sci. 2017, 4, 323-331. [CrossRef]

22. Toyomizu, M.; Hanaoka, K.; Yamaguchi, K. Effect of release of free fatty acids by enzymatic hydrolysis of phospholipids on lipid oxidation during storage of fish muscle at $-5{ }^{\circ}$ C. Bull. Jpn. Soc. Sci. Fish. 1981, 47, 605-610. [CrossRef]

23. Ojagh, S.M.; Rezaei, M.; Razavi, S.H.; Hosseini, S.M.H. Effect of chitosan coatings enriched with cinnamon oil on the quality of refrigerated rainbow trout. Food Chem. 2010, 120, 193-198. [CrossRef]

24. Reza, M.S.; Bapary, M.A.J.; Islam, M.N.; Kamal, M. Optimization of marine fish drying using solar tunnel dryer. J. Food Process. Preserv. 2009, 33, 47-59. [CrossRef]

25. Mansur, M.A.; Rahman, S.; Khan, M.N.A.; Reza, M.S.; Kamrunnahar; Uga, S. Study on the quality and safety aspect of three sun-dried fish. Afr. J. Agric. Res. 2013, 8, 5149-5155.

26. Roy, V.C. Improvement of Food Quality of Dried Bombay Duck (Harpodon nehereus) Product Using Salt and Herbal Substances. Master's Thesis, Department of Fisheries Technology, Bangladesh Agricultural University, Mymensingh, Bangladesh, 2013.

27. Rahman, M.J.; Karim, E.; Uddin, M.S.; Zaher, M.; Haque, M.A. Development of Low-Cost Emergency Fish Dryer in Bangladesh to use in absence of sunlight. Bangladesh Res. Public J. 2012, 7, 267-276.

28. Hasan, M.M.; Rasul, M.G.; Ferdausi, H.J.; Trina, B.D.; Sayeed, A.; Shah, A.K.M.A.; Bapary, M.A.J. Comparison of organoleptic and chemical characteristics of some traditional and improved dried fish products. Res. J. Anim. Vet. Fish. Sci. 2016, 4, 1-6.

29. AOAC. Official Methods of Analysis, 16th ed.; Association of Official Analytical Chemists: Arlington, VA, USA, 1995.

30. Antonocoupoulos, N.; Vyncke, W. Determination of volatile basic nitrogen in fish. Zeitschrift für Lebensmittel Untersuchung und Forschung 1989, 189, 309-316. [CrossRef]

31. Bligh, E.G.; Dyer, W.J. A rapid method of total lipid extraction and purification. Can. J. Biochem. Phys. 1959, 37, 911-917. [CrossRef]

32. Barraw, G.L.; Feltham, R.K.A. Cowan and Steel's Manual for the identification of Medical Bacteria, 2nd ed.; Cambridge University Press: Cambridge, UK, 1993. 